\title{
Bringing American Popular Culture to the English Departments in Indonesia
}

\author{
Dewi, $\mathbf{N}$. \\ Graduate Program in English Language Studies, Sanata Dharma University, Yogyakarta, INDONESIA \\ e-mail: novitadewi9@gmail.com
}

\begin{abstract}
One outcome of the globalization process is the growing influence and dominance of American popular culture. The speed with which American music, films, and goods have flooded the markets worldwide is remarkably high, thanks to the advancement of telecommunication technologies and the Internet. Increased cultural transfer or, more precisely, internationalization of American culture has posed both fear and fascination to other cultures. How do people in the academia respond to this conundrum of cross-cultural contacts? What do we teach when we teach popular culture? What viable research in American popular culture is encouraged so as to result in impartially beneficial impacts for society at large? This paper is to argue that one can become an avid learner or critic of a certain culture when s/he finds meaningful connections between that culture and life itself. The teaching of American popular culture in the English Department, for instance, has to be locally contextualized, learner-participant oriented, and socially self-actualized. In this way, American Studies outside the U. S. may in turn become less centralized as the interchange of cross-cultural understanding takes place concurrently.
\end{abstract}

Key words: Local context, learner-participant centered, promoting humanistic values.

\section{INTRODUCTION}

People become keen learners, researchers, or critics of a particular culture when they find personal meaning in it, even if the culture in question is not necessarily that of their own. What can Indonesian students, for example, make of American chicklit, movies, sitcom, reality shows, window shopping, U. S. branded products, etc.? How relevant is it to bring such films as Judas Kiss, Milk, Brokeback Mountain in an American Studies classroom in a country where the Lesbian, Gay, Bisexual and Transgender residents have hardly had civil rights protections? How do we relate studies in economics in the United States with the "Black (berry) Friday" in November 2011 when Jakarta's gadget-craze middle class crowded and jostled for the latest discounted smartphone in stupid frenzy? It is thus worth asking as to whether the study of American Popular Culture (henceforth APC) may attest to the need and hope of the Indonesians with which people may find connections between (foreign) culture and life.

This paper is to discuss research in APC which is often pursued by students doing American Studies, be they at the postgraduate level or as part of their undergraduate program in the English Departments. It will first look at the ways popular culture can be best situated in the curricula before examining some possibilities in doing research in APC in Indonesian context. It must be mentioned at the outset that the nature of this paper is of reflection notes. Therefore, the coverage of APC under discussion is limited to my own experiential inquiry in writing, teaching, and supervising students' papers/theses on some certain literary genres such as American popular fiction, comic books, films, and songs. Excluded in the discussion are other ways of life and contemporary popular cultural forms as palpably conceived in Williams (1976) as well as his seminal work on consumption.

\section{(AMERICAN) POPULAR CULTURE: TO USE OR NOT TO USE?}

The use of popular culture in academic setting has long been an issue of controversy. Most of the scholarships problematize the use of popular literature in the teaching of English as a school subject (e.g. Browne (2005) and Thurnau (2012)). The proponents of popular culture believe in its relevance to people's everyday life, to say nothing of its fun, fascinating package, especially to the young minds. The counterargument is that popular literature is lacking in language sophistication deemed necessary for students for which reason they need to be exposed 
more to the literature proper, i.e. Canon and Classics. The middle way proposed in a recent article by Thurnau, for example, is interesting; it argues that critical thinking and exciting learning experience can be obtained by the use of popular culture in conjunction with (mainstream?) literature. Thurnau mainly juxtaposes two differing opinions from, respectively, Diane Penrod's pro-pop culture approach and Carol Jago's option for the classics. Penrod examined other professors' use of popular literature in the universities across the continents before concluding that literature can change, quoted aptly in Thurnau's (2012) article, "bored youth" into "border youth". Meanwhile, Thurnau seems to be equally convinced by Jago who made use of, among others, Frankenstein to explain cloning to her students. This is to say that classical works can help people understand contemporary issues. Citing one more hands-on experience from another scholar to use as evidence, Thurnau concludes that integration of popular culture and literature can help promote students' criticical mind in order to understand the world around them better and with more empathy.

As for visual (vis-à-vis verbal/printed) popular culture like films, the debate on their use or rejection in the classroom is no less intense. Browne (2005) wrote that American Studies and popular culture are complementary, as both "have their eyes on the same stars and often holds hands as they walk the same path" (p. 22). Browne supports the teaching of subjects as different as sports, sci-fi, pulp fiction, TV, and many others in an American Studies class given the interdisciplinary nature of this program. A cursory look at various websites or blogs written by university professors of American Studies, English Studies, and Popular Culture will show that these "hip" educators try to engage with today's class by their inclusion of Hollywod hits and sometimes newest Oscar bait in the curriculum. Indeed, for decades, the use of miscellaneous teaching materials and multi-disciplinary approaches has been attempted with varying degrees of success. A recent article by Schocket (2011), for instance, displays some reservation about the use of children's animated films Liberty's Kids broadcast by the U. S. public television network on the ground of possible distorted representations of American history. Meanwhile, Klein (2008) uses instead Korean films Memories of Murder and the Host by reknown director Bong Joon-ho as a teaching material to examine the authoritarian regime in Korea alongside the country's rift with the American government. To move closer to home, in China, as shown by Wang (2003), Cultural Studies is taught by introducing Western movies, television, and many other cultural expressions to suit the Chinese context in order to engage in a meaningful transnational dialogue in this age of globalization.
In sum, the pros and cons of using popular culture still vary from individual, institutional, and nation-state levels. But, it can be said that APC with all its strengths and weaknesses need to be used, facilitated, and appropriated in accordance to the respective learning goals. Educators need to take advantage of the attraction and pertinent newness of popular culture to help explore today's issues without leaving behind the conventional products of culture. With this in mind, the next section will attempt to situate APC within the Indonesian context, focusing as it does on research or writing in the subject that graduate students in American Studies and/or English Departments can possibly do.

\section{WHAT TO RESEARCH AND WHAT FOR?}

To engage in a research means to demonstrate one's intellectual competence and social commitment. As such, any research in APC has to accommodate both needs. Very often, however, APC theses are materialbased; hence do not really improve life-quality owing to their deficiency in authentic human interactions. Consider, for example, the following titles "Greed and Guilt in The Devils Wear Prada", "Seven Deadly Sins in Award Winning Movies 2000-2010", "After 9/11: American Crime Fiction Revisited", "Shop till You Drop: Consumption in American and British Chicklit", etc. Admittedly, it is not always easay to write with erudition on any foreign culture which has little bearings with the local needs. Susan Huddleston Edgerton (via Pendewasaan Etos Akademik Lewat Thesis [Sanata Dharma University Document, n.d., p. 24) has expressed similar concern regarding the difficulty in integrating cultural studies into one's work and life in her Translating the Curriculum Murticulturalism into Cultural Studies (1996). Next, to learn from my own anxiety about research/writing in English Literature, it is evident that undergraduate theses often read like opinion papers adorned here and there with most-often-quoted jargons in contemporary literary criticisms from Structuralism to Postfeminism. It so happened that the thought-to-be-goodthesis is repeatedly sampled for the writing of other theses with little or no alteration at all (Dewi, 2006; Dewi, 2009; Dewi, 2011). Adjustable templates are also rich (read: poor) and aplenty: "Character Development of... [name of character(s)] in ... [title of work]", "Setting and Plot in ... [title of work]: A ... [name of approach/criticism] Reading"; the more complex one being "Freudian Fantasy Refuted in Three Woman Novelists", etc. Plagiarism is hence here to stay (Dewi, 2006a). As it is, no knowledge transfer is at play in such exercises, let alone academic integrity. Considering that research in APC is sometimes embedded in the English literary research, such frauds may likely occur time and again. 
In view of English as a lingua franca or what Graddol (2006) called "World English", Bismoko (2009) claims that the study of English in non-Englishspeaking countries today should be essentially comparative and expression of local culture. To his eye, "Doing research in English studies the classicist way today, including research in English literature, may represent an opportunity loss or even regression" (p. 6). Bismoko further suggests several areas for development in terms of research assumptions (part of knowledge acquisition, life-quality improvement, deductive-inductive knowledge, naturalistic and progressive research) and research-report evaluation. As such, English literature research should be comparative, contextualized, and participant-oriented (cfr. student-centered learning in education), than the otherwise centralistic toward American or British Literature.

It can be argued that this postmodernist vision (see also Bismoko, 2011) is applicable to APC research in the Indonesian setting, if one is to account for the academic competency and humanistic values mentioned in the beginning of this section. Localcontext dependent, community-oriented humanities studies can therefore become an appropriate model for APC. What follows is brief commentary on bonum commune research of this kind.

Contextualised. Nearly all popular culture is American, given the persuasive power, globalization, technologization, and political economy of the United States. As a result, American domination continues to presage every time and everywhere that particular culture travels. To talk about APC without addressing this inequity is impractical and stagnant in theory and praxis alike. To illustrate, in this gadget-craze age and consumer-oriented society, kids in the U. S. were reportedly born to buy. Unlike American children in the past who occasionally treated themselves to jellybean at a candy store, says Marissa O'Connell (2010), today's tweens (aged 8 to 12) would rather frequent Apple store, because the bright, colorful iPod, to name one, is just as mouthwatering. This is just one of many consumption realities which has possibly made ordinary Indonesian children (as well as parents) alienated. Any research on American consumerism, for example, should raise critical awareness on the part of the desperately seeking Indonesian consumer society. Given the glaring economic imbalance, local problem-solving research would be more appreciated than the one focusing simply on cultural issues too distant to grapple with.

Humanistic. The teaching and writing of APC should promote the growth of ethical responsibility and bond of larger human communities. The goal is to make individuals truly autonomous, self-fulfilled and emancipated (Alvesson \& Skoldberg, 2000, p. ?). Research in APC can then be pursued in juxtaposition with its local variants. Research on Jogjakarta's Hip Hop community and their regular performances in the Bentara Budaya Jogja of "Jazz Mben Senin" [Playing Jazz music every Monday], for example, may enrich studies on this genre of music. On a personal note, the vision and mission of Sanata Dharma University, Yogyakarta, is to promote further the dignity of the Indonesian society. Central to the education system herein is a communal care for students in pursuit of wisdom, psychological maturity, spiritual depth, social solidarity, and global awareness. Under a collaborative research on English Studies for Peace, for example, the students have been encouraged to develop their own related topics for their graduating papers and/or theses. The strand of topics emerged include "Interfaith in Indonesian and American Popular Novels", "Territorial Mapping in Somerset Maugham's 'Asia' Short Stories", "Translation and Transnationality in Pramoedya Early Works", and many more.

Research Participant Voiced. Methodologically speaking, research in cultural studies should be subjectively objective. Data gathering therefore should be locally informed, historically situated, and ideologically driven as the researcher and her/his participants see it fit (Saukko, 2003; Creswell, 2007). While close reading of texts remains useful, ethnographic and lived experience research methods are worthtrying. Research in APC using lived experience will focus on the perception and meaningful experience of the research participant(s), and how they make sense of the continually shifting realities in their day-to-day encounters with American culture. A research on die-hard fans of American Idol, for instance, will have some important bearings on the commodification and gullibility of viewers of Indonesian singing contests and other pertinent competitions. It is expected that resistant voice(s) can be heard from such examination to challenge the usual normativity and top-down conclusions in classicist media studies.

Thus being said, APC research in Indonesia is necessarily a comparison and contrast pursuit. More efforts should be made to bring together the culture of the U. S. and its implications in Indonesia and viceversa. The knowledge productions and dissemination thereof should come from both ways. To name one teaching notes, O'Neil and Schur (2006) made their American Studies students in the U. S. exchange information and communicate via e-mails with students in Turkey doing American Studies. The result is satisfactory for this method has enhanced 
cross-cultural understanding among the students. They also maintain that their experiment not only helps globalize American Studies worldwide but also broaden the intellectual pool of international scholars. While the study of O'Neill and Schur here is important, note should be taken however that in the light of postmodernism, the broadening of intellectuals should bring about positive impacts on unresolved problems outside the academe as well. Only then can the studies of any culture create equity in this, flawed, world. It is on this emancipating and progressive basis that research in APC should firmly stand.

\section{CONCLUSION}

Before concluding, let me share a story about my friend Sivagnanam Jeyasankar. An acomplished scholar and fine Kooththu dancer, in early 2000s Jeyasankar began to establish the "Third Eye Local Knowledge and Skill Activist Group" in his hometown Batticaloa, Sri Lanka. This community theatre is concerned with the preservation and development of Kooththu as one of the many cultural treasures of Sri Lanka soon to disappear if globalbased digital arts and entertainment take over. Although Jeyasankar has warmly welcomed numerous overseas scholars and been helpful resource person on Kooththu, this poet and lecturer (and now Head of Department) at the Eastern University at Batticaloa has lamented the scarcity of scholarly writing on Koththu easily accessible to the community that performs it. He is convinced that such a gap is partly resulted from the colonizing nature of research by the university academics who mostly write to seek promotion, research funding, and publications in internationally refereed journals, hence ignoring the contribution and usefulness of research of this kind to society. Mentioned must be made here that Jeyasankar's Third Eye has drawn scholarly attention as shown in several international articles or books on Kooththuu citing this theatre group. Drawing on various decolonizing minds in the like of Paolo Freire, Martin Brian, and, especially, Linda Tuhiwai Smith, Jeyasankar himself wrote an interesting article about this colonial construction of the Sri Lankan education system whereby most intellectual exercises such as teaching, research, and grant-seeking were mostly conducted under the imperial eyes. He has this to say about the alienation of the local people who could have otherwise benefited from some academic works.

In the various aspects of research, intellectuals treat the local environment and local people merely as resources bases but not as problem-solving spaces or spaces for change. These resource bases are not the beneficiaries of conventional research or academic work and in most instances are not even aware of the final product of the research (Jeyasankar, 2004, np).

It is clear here that Jeyasankar's narrative, future existence of Koththu, and the country's ongoing imperial research can become a kind of lessons learnt for the present discussion on conducting research in APC. Indeed, Sri Lanka is not Indonesia. Nor is each respective relation with the United States of America the same. Nonetheless, both countries have shared experiences and common pursuit, i.e. to brave the new technologized world and unstoppable globalization of the dominant American culture (or any culture for that matter.) Thus, if research products in American Popular Culture in Indonesia can somehow help, the appealing yet appalling face of global connectivity may yield exciting challenges to help build our world anew: a world full of peace and equity.

\section{REFERENCES}

Alvesson, M. \& Skoldberg, K. (2000). Reflexive methodology: new vistas for qualitative research. London: Sage Publications.

Bismoko, J. (2009). Doing research in EFL literature. Yogyakarta: Graduate Program in English Studies Sanata Dharma University.

Bismoko, J. (2011, December 8-10). Postmodern english education system: Making it work. Address at the Keynote Speech at the $16^{\text {th }}$ ESEA Conference, Yogyakarta.

Browne, R. B. (2005). American studies and popular culture. In Browne, R. B. (Ed.), Popular culture studies across the curriculum (pp. 17-23). Jefferson: McFarland \& Company, Inc. Retrieved from www.mcfarlandpub.com/.../07864-2024-3.C.

Creswell, J. W. (2007). Qualitative inquiry and research design (2nd ed.). London: Sage Publications.

Dewi, N. (2006). As simple as ABC. Phenomena: Journal of Language and Literature, 10, 49-57.

Dewi, N. (2006a). Membaca, menulis, dan membaca untuk menulis: diagnosis dini penulisan karya tulis di fakultas sastra [Reading, writing, and reading for writing: an early diagnose on graduate paper writing in the faculty of letters]. Susastra 3: Jurnal Ilmu Sastra dan Budaya, 2 (3), 20-35.

Dewi, N. (2009). Quo vadis english studies di indonesia? [Quo vadis english studies in Indonesia] In S. Wibowo (Ed.), Manusia teka-teki yang mencari solusi [Puzzled human in search of solutions] (pp. 199-211). Yogyakarta: Kanisius. 
Dewi, N. (2011). Arah kajian sastra: ciptakan dunia perempuan yang lebih baik [Direction of literature studies: create a better world for women]. In Taum, Y.Y. et al. (Eds.), Bahasa, sastra, dan budaya indonesia dalam jebakan kapitalisme (pp. 135-145). Yogyakarta: Penerbit Universitas Sanata Dharma.

Graddol, D. (2006). English next: why global english may mean the end of english as a foreign language. Britain: British Council.

Jeyasankar, S. (2004, November). Research through imperial eyes. Retrieved from Tamil Canadian http:// www.tamilcanadian.com/page.php?id $=2658$.

Klein, C. (2008). Why american studies needs to think about korean cinema, or, transnational genres in the films of bong joon-ho. American Quaterly, 60 (4), 871-898.

O'Conell, M. (2010, July). Candy shop culture: how adults can affect tween consumerism. Emerging Popular Culture Corner. Retrieved from http://www.americanpopularculture.com/archive /emerging/consumerism.htm
O’Neil, M. and R. Schur. (2006). Creating crossculural encounters in the american studies classroom. American Studies, 47 (3/4), 137-149.

Saukko, P. (2003). Doing research in cultural studies. London: Sage Publications.

Schocket, A. M. (2011). Little founders on the small screen: interpreting a multicultural american revolution for children's television. Journal of American Studies, 45 (1), 145-163.

Thurnau, J. E. (2012, December 1). Popular culture vs classical literature in the english classroom. Retrieved from voices.yahoo.com/shared/print_ shtml? content type $=$ article\&content type id...

Wang, N. (2003). Cultural studies in china: towards closing the gap between elite culture and popular culture. European Review, 11, 183-191.

Williams, R. (1976). Keywords: a vocabulary of culture and society. London: Oxford University Press.

\footnotetext{
* An earlier version of this paper was presented as an Invited Speech at the International Conference on "American Popular Culture in Hemispheric and Global Mind", Faculty of Cultural Science, Gadjah Mada University, Yogyakarta, 29 February 2012.
} 